\title{
POLA GRAF PADA ARUS LALU LINTAS PEREMPATAN SRENGSENG
} KEMBANGAN JAKARTA BARAT

\author{
Choirul Basir \\ Program Studi Matematika, Universitas Pamulang \\ *Corresponding Author Email: dosen02278@unpam.ac.id
}

\begin{abstract}
Everyday problems can be translated into mathematical language so as to produce a picture of an accurate and well-visualized solution. The regulation of highway traffic flow can also be described in graphs so that an optimal solution is obtained from traffic problems that actually have complex problems. But at least, when the traffic flow is visualized in the form of graphs it will be easier to find a solution. As happened in the flow of traffic at the Srengseng Kembangan crossroad, West Jakarta, which is included in an area with quite a level of congestion because it is the main road connecting the suburbs of Jakarta with Jakarta, connecting West Jakarta with South Jakarta and Central Jakarta. After the graph pattern of the Srengseng intersection is made, then a traffic flow observation is carried out in order to get the knot coloring model to produce chromatic numbers $\chi(G)=4$ and side coloring results in chromatic numbers $\chi(G)=4$ as well to further optimize traffic flow to make it more smoothly.
\end{abstract}

Keywords: Graph, Graph Theory Application, Traffic.

\begin{abstract}
ABSTRAK
Permasalahan sehari-hari dapat diterjemahkan kedalam bahasa matematika sehingga menghasilkan gambaran solusi yang akurat dan tervisualisasi dengan baik. Pengaturan arus lalu lintas jalan raya juga dapat digambarkan dalam bentuk graf sehingga didapatkan solusi optimal dari permasalahan lalu lintas yang sebenanya memiliki masalah yang kompleks. Tapi paling tidak, ketika arus lalu lintas tervisualisasikan dalam bentuk graf maka akan lebih mudah mencari solusinya. Seperti yang terjadi pada arus lalu lintas di perempatan Srengseng Kembangan Jakarta Barat yang termasuk wilayah dengan tingkat kemacetan lumayan karena merupakan jalan utama yang menghubungkan wilayah pinggiran Jakarta dengan Jakarta, menghubungkan Jakarta Barat dengan Jakarta Selatan dan Jakarta Pusat. Setelah pola graf dari perempatan Srengseng dibuat, selanjutnya dilakukan pengamatan arus lalu lintas sehingga didapatkan model pewarnaan simpul nya menghasilkan bilangan kromatik $\chi(G)=$ 4 serta pewarnaan sisinya menghasilkan bilangan kromatik $\chi(G)=4$ juga untuk lebih mengoptimalkan arus lalu lintas agar lebih lancar.
\end{abstract}

\section{Kata kunci: Graf, Aplikasi Teori Graf, Lalu lintas.}

\section{PENDAHULUAN}

Awal mula penggunaan graf pada masalah jembatan Konigsberg di kota Kaliningrad Rusia di tahun 1736, ada tujuh jembatan yang menghubungkan daratan tersebut. Masalah jembatan Konigsberg adalah apakah mungkin melewati masing-masing ketujuh jembatan tersebut tepat sekali dengan syarat harus kembali ketitik awalnya?

Pada tahun 1736 juga ada seorang matematikawan Swiss bernama L. Euler yang dapat 
memecahkan permasalahan tersebut dengan sederhana. Euler memodelkan masalah jembatan Konigsberg dalam model graf dimana daratan disimbolkan dengan simpul (vertex) yang ditandai dengan abjad A, B, C, D sedang jembatan disimbolkan dengan sisi (edges) seperti terlihat pada Gambar 1.1.

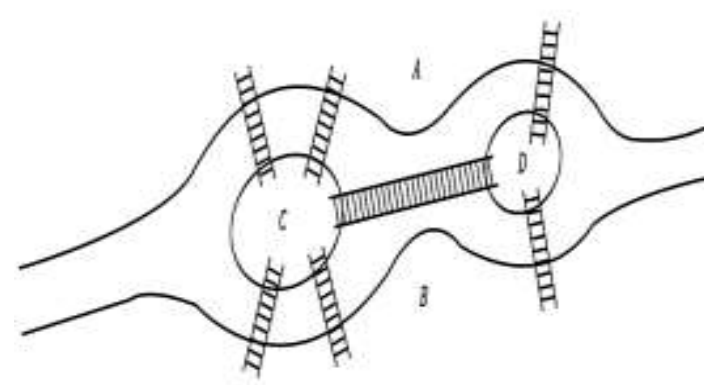

(a)

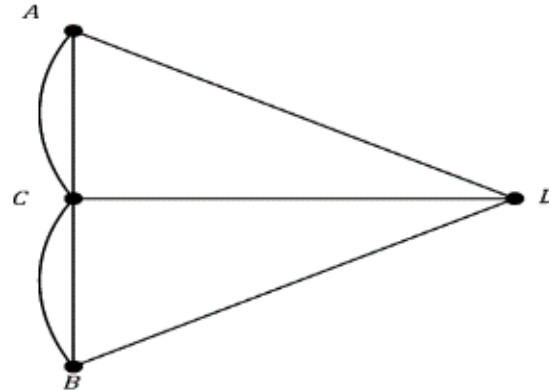

(b)

Gambar 1.1 (a) Ilustrasi jembatan Konigsberg

(b) Model permasalahan Jembatan Konigsberg menurut Euler

Akhirnya Euler mengambil kesimpulan bahwa mustahil orang dapat melalui tepat sekali ketujuh jembatan untuk kembali ke titik awal pemberangkatan.

\section{Definisi 1:}

Graf $\mathrm{G}$ didefinisikan sebagai pasangan himpunan (V,E), ditulis dengan ditulis dengan notasi $\mathrm{G}=(\mathrm{V}, \mathrm{E})$, dengan $\mathrm{V}$ adalah himpunan tak kosong dari simpul-simpul (vertex) dan $\mathrm{E}$ adalah himpunan sisi (edges) yang menghubungkan sepasang simpul (Rinaldi Munir, 2016).

Definisi 1 mengatakan bahwa $V$ tidak boleh kosong, sedangkan $E$ boleh kosong. Jadi sebuah graf dimungkinkan tidak mempunyai sisi satu buah pun, tetapi simpulnya harus ada. Secara umum dapat dituliskan sebagai:

$$
V=\left\{v_{1}, v_{2}, \ldots, v_{n}\right\} \text { dan } E=\left\{e_{1}, e_{2}, \ldots, e_{n}\right\} .
$$




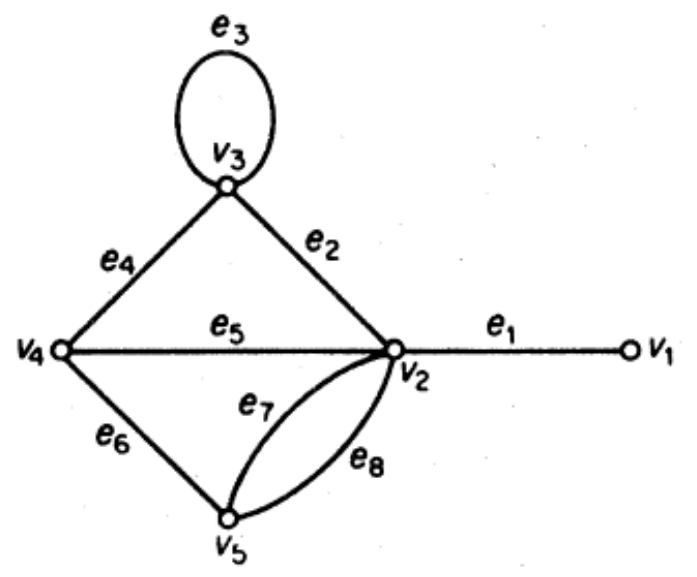

Gambar 1.2 contoh graf

Pada Gambar 1.2 didapatkan sisi ganda pada sisi yang menghubungkan $v_{2}$ dan $v_{5}$ yaitu $e_{7}$ dan $e_{8}$, sedang looping terjadi pada simpul $v_{3}$ yaitu pada sisi $e_{3}$.

\section{Unsur-Unsur Graf}

a. Simpul (Vertex) adalah daratan ( titik - titik yg dihubungkan oleh jembatan ), yang dinyatakan sebagai titik (noktah).

b. Sisi (Edge) adalah jembatan yang dinyatakan sebagai garis.

\section{Komponen Graf}

- Alur adalah setiap lintasan yang semua titik simpul berbeda satu sama lain kecuali titik awal dan titik akhirnya.

- Panjang adalah banyak sisi / lintasan yang ditempuh.

- Derajat (Degree) adalah jumlah sisi (edge) yang menuju satu titik simpul.

- Titik terasing adalah titik yang tidak memiliki garis penghubung / jalan.

- Jalan tapak adalah suatu lintasan yang tidak memiliki dua sisi yang sama.

- Ketetanggan (Adjacent) adalah dua buah simpul dikatakan bertetangga bila keduanya terhubung langsung.

- Simpul terpencil adalah simpul yang tidak mempunyai sisi yang bersisian dengannya.

- Graf Kosong adalah graf yang himpunan sisinya merupakan himpunan kosong $\left(N_{n}\right)$.

- Siklus atau sirkuit adalah lintasan yang berawal dan berakhir pada simpul yang sama.

- Panjang sirkuit adalah jumlah sisi dalam sirkuit tersebut. 
- Terhubung (Connected) adalah dua buah simpul $v_{1}$ dan simpul $v_{2}$ disebut terhubung jika terdapat lintasan dari $v_{1}$.

Graf berarah $G$ dikatakan terhubung jika graf tidak berarahnya terhubung (graf tidak berarah dari $G$ diperoleh dengan cara menghilangkan arahnya). Dua simpul, $u$ dan $v$, pada graf berarah $G$ disebut terhubung kuat (strongly connected) jika terdapat lintasan berarah dari $u$ ke $v$ dan juga lintasan berarah dari $v$ ke $u$. Jika $u$ dan $v$ tidak terhubung kuat tetapi terhubung pada graf tidak berarahnya, maka $u$ dan $v$ dikatakan terhubung lemah (weakly connected). Graf berarah $G$ disebut graf terhubung kuat (strongly connected graph) apabila untuk setiap pasang simpul sembarang $u$ dan $v$ di $G$, terhubung kuat. Kalau tidak, $G$ disebut graf terhubung lemah.

- Upagraf dan Komplomen Upagraf Komplemen dari upagraf $G_{1}$ terhadap graf $G$ adalah graf $G_{2}=\left(V_{2}, E_{2}\right)$ sedemikian sehingga $E_{2}=E-E_{1}$ dan $V_{2}$ adalah himpunan simpul yang anggota-anggota $E_{2}$ bersisian dengannya. Komponen graf (connected component) adalah jumlah maksimum upagraf terhubung dalam graf $G$.

- Cut Set adalah himpunan sisi yang bila dibuang dari $G$ menyebabkan $G$ tidak terhubung. Jadi, cut-set selalu menghasilkan dua buah komponen.

- Graf berbobot adalah graf yang setiap sisinya diberi sebuah harga (bobot).

\section{Pewarnaan Graf}

Dalam pewarnaan graf bukan hanya mewarnai simpul atau sisi atau wilayah dengan warna yang berbeda dengan simpul atau sisi atau wilayah tetangganya, namun diharapkan warna tersebut merupakan jumlah minimum warna yang dimungkinkan.

Jumlah warna minimum yang dapat digunakan untuk mewarnai simpul atau sisi atau wilayah disebut Bilangan Kromatik dari graf biasanya dilambangkan dengan $\chi(G)$.

Pewarnaan graf meliputi 3 jenis, yaitu:

\section{Pewarnaan Simpul (vertex)}

Perwarnaan simpul merupakan pewarnaan yang memberikan warna yang berbeda untuk simpul yang bertetanggaan.

Sebagai contoh:

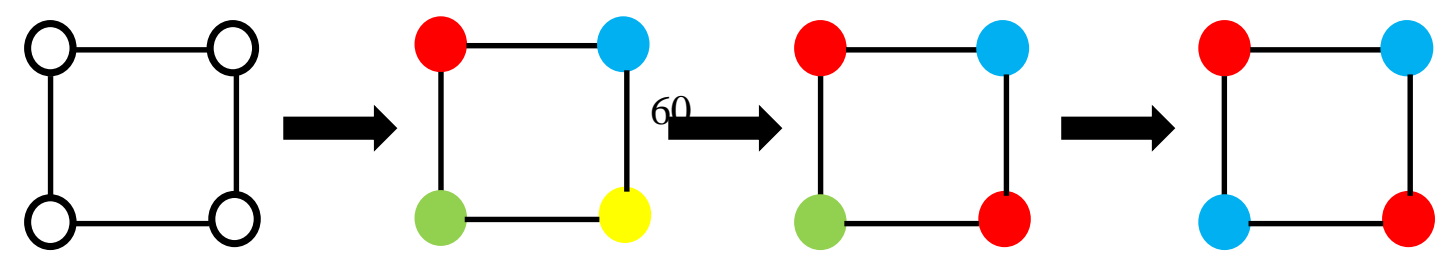


Gambar 1.3 Pewarnaan simpul

Jadi dari contoh di atas terdapat bilangan kromatik $\chi(G)=2$.

2. Pewarnaan Sisi (edge)

Perwarnaan sisi merupakan pewarnaan yang memberikan warna yang berbeda untuk sisi yang bertetanggaan. Sebagai contoh:

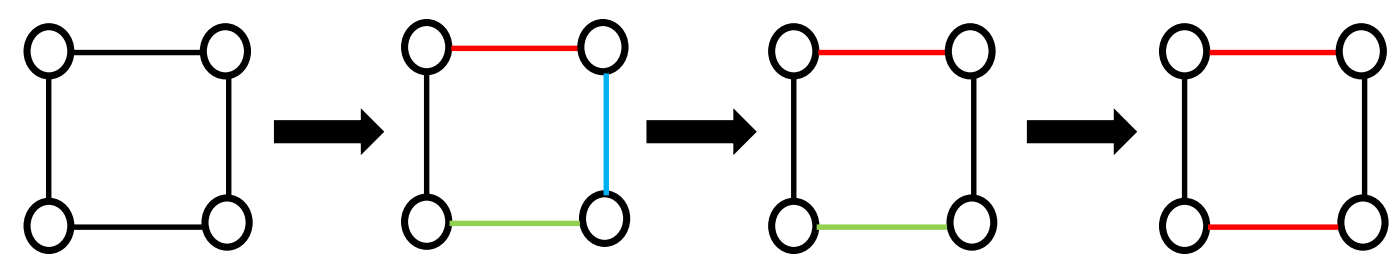

Gambar 1.4 Pewarnaan sisi

Jadi dari contoh di atas terdapat bilangan kromatik $\chi(G)=2$.

Bilangan kromatik $\chi(G)$ pada pewarnaan sisi graf dapat dituliskan:

$$
c(v) \leq d(v)
$$

dengan $c(v)$ merupakan pewarnaan sisi dan $d(v)$ merupakan derajat (degree) dari simpulnya. (John Adrian Bondy dan Murty, 1982)

3. Pewarnaan Wilayah (region)

Perwarnaan sisi merupakan pewarnaan yang memberikan warna yang berbeda untuk wilayah yang bertetanggaan. Sebagai contoh:
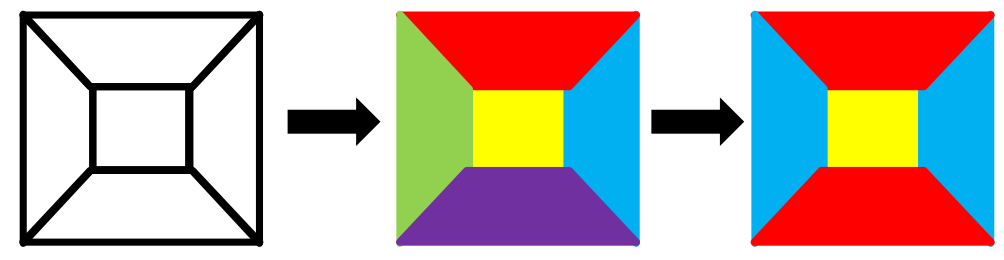

Gambar 1.5 Pewarnaan wilayah

Jadi dari contoh di atas terdapat bilangan kromatik $\chi(G)=3$.

\section{METODOLOGI}

Bilangan kromatik merupakan salah satu bahasan pada teori graf yang dapat digunakan untuk melihat antar simpul (vertex) tidak terjadi warna yang sama ketika simpul tersebut 
tehubung (connected). Untuk permasalahan pada lalu lintas maka bilangan kromatik ini dapat membantu untuk melihat terjadinya arus lalu lintas yang akan mengalami berbentrokan sehingga dapat membantu menyelesaikan masalah lalulintas secara efektif dan efisien. Beberapa langkah yang dilakukan adalah sebagai berikut:

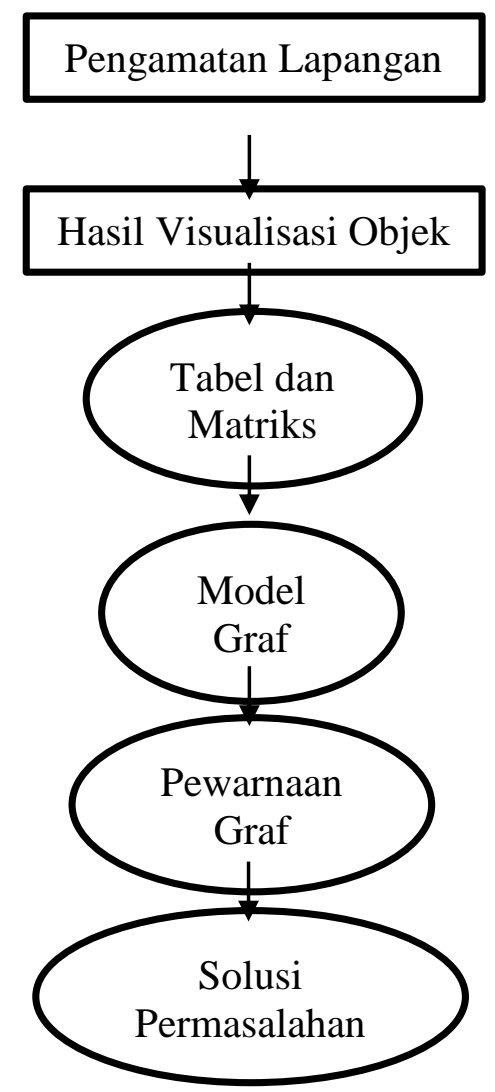

Gambar 2.1 Alur penyelesaian masalah

\section{HASIL DAN PEMBAHASAN}

\subsection{Data Penelitian}

Berikut merupakan gambaran alur lalu lintas di perempatan Srengseng Kembangan Jakarta Barat: 


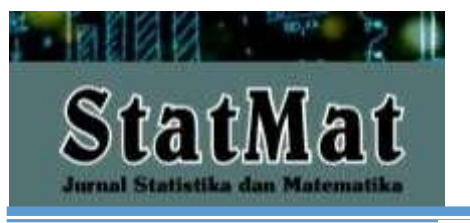

P-ISSN: 2655-3724

STATMAT (Jurnal Statistik dan Matematika), Vol. 2, No. 1, 2020

Halaman: 57-65

@Prodi S-1 Matematika FMIPA Unpam

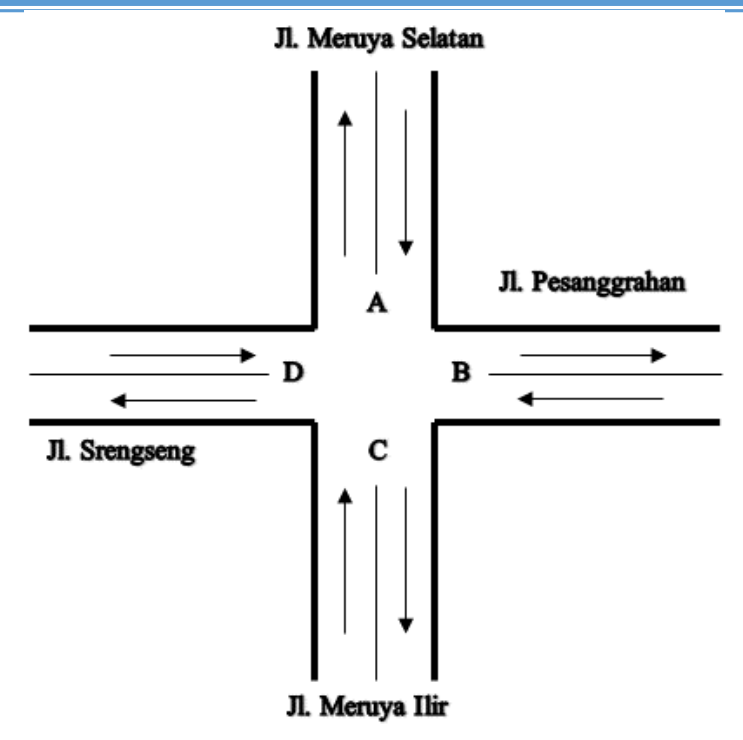

Gambar 3.1 Perempatan Srengseng Kembangan Jakarta Barat

dari Gambar 3.1 didapatkan bawah terdapat jalur dari A ke B, A ke C, A ke D, B ke A, B ke C, B ke D, C ke A, C ke B, C ke D, D ke A, D ke B, dan D ke C.

Jalur tersebut dapat dituliskan dalam tabel sebagai berikut:

Tabel 3.1 Nilai Alur Lalu Lintas Perempatan Srengseng

\begin{tabular}{ccccc}
\hline Jalur & A & B & C & D \\
\hline A & 0 & 1 & 1 & 1 \\
B & 1 & 0 & 1 & 1 \\
C & 1 & 1 & 0 & 1 \\
D & 1 & 1 & 1 & 0
\end{tabular}

Jika dituliskan dalam bentuk matriks alur lalu lintas perempatan Srengseng sebagai berikut:

$$
P=\left[\begin{array}{llll}
0 & 1 & 1 & 1 \\
1 & 0 & 1 & 1 \\
1 & 1 & 0 & 1 \\
1 & 1 & 1 & 0
\end{array}\right] .
$$

Matriks di atas menggambar kan ada tidaknya arah menuju ke jalur tersebut sesuai dengan Tabel 3.1.

\subsection{Pembahasan}

Jika dilakukan pewarnaan simpul (vertex) pada arus lalu lintas perempatan Srengseng Kembangan Jakarta Barat tersebut graf di atas menjadi: 


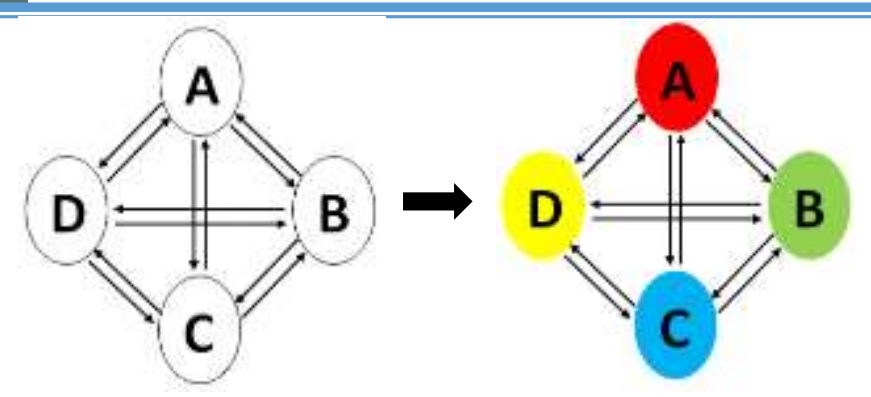

Gambar 3.1 Proses pewarnaan simpul (vertex)

Setiap simpul (vertex) terhubung dengan simpul (vertex) yang lain sehingga menghasilkan bilangan kromatik $\chi(G)$ sejumlah simpul (vertex). Perempatan Srengseng jika digambarkan secara graf memperlihatkan terdiri dari 4 buah simpul (vertex) dan 12 sisi (edge) yang menghubungkan. Setiap simpul saling terhubung dengan rincian masing-masing simpul (vertex) 3 in dan 3 out, maka bilangan kromatik $\chi(G)$ adalah 4 sehingga terlihat menghasilkan 4 warna yang berbeda.

Jika dilakukan pewarnaan sisi (edge) pada arus lalu lintas perempatan Srengseng Kembangan Jakarta Barat menghasilkan pola graf berikut:
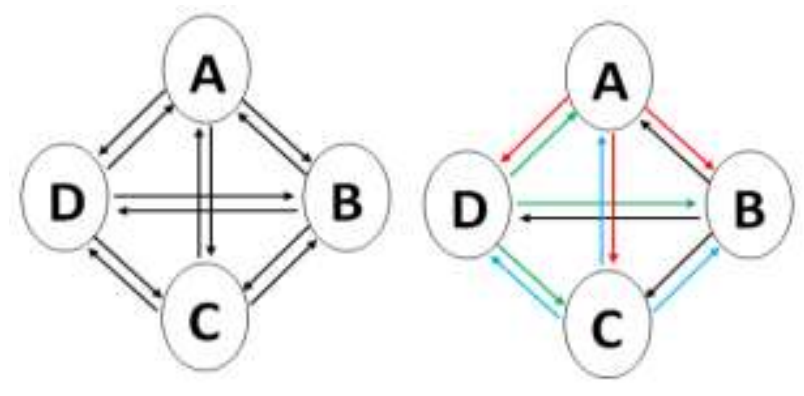

Gambar 3.2 Proses pewarnaan sisi (edge)

Sisi-sisi (edges) yang menghubungkan simpul (vertex) menghasilkan bilangan kromatik $\chi(G)$ juga yang mempengaruhi arus lalu lintas. Arus lalu lintas akan optimal jika warna nya sama, tetapi jika warna yang berbeda terjadi arus lalu lintas secara bersamaan maka akan ada bentrokan arus lalu lintas. Bilangan kromatik $\chi(\mathrm{G})$ yang dihasilkan dari kasus ini $\chi(\mathrm{G})=4$.

Meskipun dilakukan skema belok ke kiri jalan terus pun akan didapatkan bilangan kromatik $\chi(G)$ yang sama yaitu 4 , tetapi akan menghasilkan beda proses kelancaran arus lalu lintas di bandingkan mengikuti pola pada Gambar 3.2. 


\section{SIMPULAN DAN SARAN}

\subsection{Simpulan}

Bilangan kromatik $\chi(\mathrm{G})$ pada pewarnaan simpul (vertex) yang dihasilkan sejumlah dengan simpulnya jika setiap simpulnya terhubung (connected). Untuk kasus perempatan jalan jika setiap ruas jalannya terdapat lajur dua arah maka akan menghasilkan bilangan kromatik $\chi(\mathrm{G})$ yang lebih dari sama dengan jumlah derajat masuk $\left(d_{i n}\right)$ atau derajat keluar $\left(d_{\text {out }}\right)$ nya. Dalam kasus ini menghasilkan bilangan kromatik $\chi(\mathrm{G})=4$.

Untuk kasus perempatan jalan yang setiap ruasnya terdapat dua lajur berlawanan maka diharapkan diberlakukan belok kiri jalan terus karena jika tidak diberlakukan belok kiri jalan terus akan mengakibatkan lamanya durasi lampu merah pada masing-masing simpul.

\subsection{Saran}

Dilakukan simulasi untuk segala jenis model perempatan sebagai contoh kasus berikut ini:

1. Perempatan dengan 1 ruas jalan yang terdiri dari lajur bolak balik sedang 3 ruas lainnya hanya lajur searah.

2. Perempatan dengan 2 ruas jalan yang terdiri dari lajur bolak balik sedang 2 ruas lainnya hanya lajur searah.

3. Perempatan dengan 1 ruas jalan yang terdiri dari lajur bolak balik sedang 1 ruas lainnya hanya lajur searah dan lain-lain.

Kasus ini pun masih dapat dikembangkan pada simulasi jika ruas searahnya masuk atau keluar saja atau kombinasi ruas yang searah adalah masuk dan keluar. Jika semua simulasi kemungkinan arus lalu lintas yang mungkin maka akan didapatkan formula yang paling efektif arus lalu lintas untuk model jalan berupa perempatan sehingga mengasilkan jalan yang lancar tanpa harus melebarkan luas jalan.

\section{DAFTAR PUSTAKA}

Munir, Rinardi. 2003. Metode Diskrit. Informatika, Bandung.

Bondy, John Adrian and Murty, U.S.R. 1982. Graph Theory With Applications. North Holland, Amsterdam. 